\title{
Migrant workers' access to remedy for exploitation in Australia: The role of the national Fair Work Ombudsman
}

\author{
Laurie Berg $^{\mathrm{a}}$ and Bassina Farbenblum ${ }^{\mathrm{b}}$
}

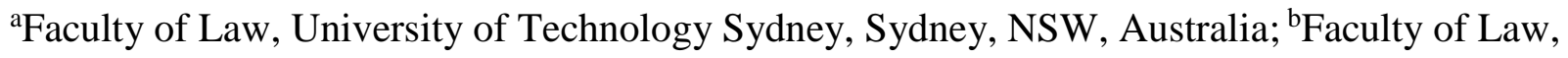
University of New South Wales, Sydney, NSW, Australia;

\begin{abstract}
Exploitation of temporary migrant workers in Australia has emerged as a significant human rights concern. However, limited attention has been paid to the State's responsibility to ensure individual workers can access remedies for rights violations. This article considers whether Australia's government agencies and institutional frameworks are suitable to enabling remedies for temporary migrant workers, and how well they deliver remedies to individuals in practice. Drawing on new empirical data, it focuses on the role of the national labour inspectorate, the Fair Work Ombudsman (FWO).
\end{abstract}

FWO has undertaken various education, compliance and deterrence initiatives directed to systemically improving conditions for migrant workers. This article considers the extent to which individual migrant workers seek assistance from FWO to recover their personal unpaid wages, and the remedial outcomes of individual claims lodged with the agency. We illuminate structural factors contributing to migrants' reluctance to engage with FWO, as well as factors contributing to low wage recovery rates for those who do contact FWO. We conclude that although these challenges are numerous and multi-layered, they are not all inevitable. Reforms should incorporate a new migrant-centred approach that recalibrates the risks and costs of seeking remedies against the likelihood of obtaining a just outcome. 


\section{KEYWORDS}

Migrant worker, Fair Work Ombudsman, access to justice, access to remedy, exploitation, international students

\section{CONTACT}

laurie.berg@uts.edu.au

b.farbenblum@unsw.edu.au

\section{Introduction}

In the last five years, the exploitation of low-waged temporary migrant workers in Australia has emerged as a significant human rights concern. Poor working conditions, especially for international students and backpackers, have been repeatedly brought into the spotlight by media exposés. Policy-makers and labour law experts are now grappling with the regulatory challenge of preventing such rights violations (Campbell, Boese, and Tham 2016; Howe 2016). However, limited attention has been paid to the core state responsibility to ensure these workers can access remedies for rights violations. If a 'basic test of a labour law regime is the enforcement of minimum wage and other entitlements' (Arup and Sutherland 2009, 96), there are serious questions to be addressed regarding whether Australia's government agencies and institutional frameworks are in fact suitable to enabling remedies for low-waged temporary migrant workers, and how well they deliver remedies to individuals in practice.

This article considers the mechanisms available to individual migrant workers to access remedies for their unpaid wages in Australia, focusing in particular on the role played by the national labour inspectorate, the Fair Work Ombudsman (FWO). Our focus is on temporary visaholders who have work rights (such as international students, backpackers and employersponsored 457 visa-holders) but lack residence and citizenship. ${ }^{1}$ Recognising the vulnerability and systemic mistreatment of this workforce, since 2012 FWO has increasingly prioritised

\footnotetext{
${ }_{1}^{1}$ We address these issues as they relate to unauthorised workers in a forthcoming publication (Berg and Farbenblum, forthcoming).
} 
migrant workers in its outreach and education efforts, deterrence actions, and investigatory campaigns aimed at preventing future exploitation. These efforts to safeguard the rights of migrant workers have been accompanied by a range of broader government initiatives, parliamentary inquiries, legislative amendments and, from 2016, a national inter-agency taskforce.

Against the backdrop of this agenda for structural transformation to prevent exploitation, this article explores the extent to which individual migrant workers seek assistance from FWO to recover their personal unpaid wages, and the remedial outcomes of individual claims lodged with the agency. We illuminate a number of structural challenges to individual rights enforcement that have remained under-examined and, to date, untargeted in reform efforts. Understanding these challenges is critical because court-based remedies are practically inaccessible to most lowwaged migrant workers and very few workers are members of trade unions. This leaves individuals with no viable alternative pathways for redress.

Our analysis draws on a range of new data sources obtained within a broader study on temporary migrant workers' access to justice in Australia. Because of the limited number of cases that go to court and the even smaller number of reported decisions, we conducted field research with a range of stakeholders and used multiple channels to include the views and experiences of migrant workers. We conducted 36 interviews with government agencies, legal service providers, advocates, unions, researchers and individual migrant workers between 20 January 2016 and 17 February 2017 in Sydney, Melbourne, Brisbane, Adelaide and Canberra. For background purposes, we interviewed three officers from FWO, and also held six focus groups with 26 temporary migrants during this period. In September to December 2016, along with Stephen Clibborn (University of Sydney Business School), we conducted an online temporary migrant worker survey (TMW Survey) which yielded 4322 responses from individuals who have worked on a temporary visa in Australia. Our analysis also draws upon case data and information supplied by FWO and the Department of Immigration and Border Protection (DIBP), including on FWO's handling of migrant worker complaints in 2014-2015. 
The article begins with a short account of the nature and incidence of exploitation of temporary migrant workers in Australia, followed by an overview of the three principal pathways to redress for underpaid workers: unions, the courts and FWO. The article then sets out in more detail FWO's progress in detecting and deterring exploitation of migrant workers. The remainder of the article examines individual migrant workers' access to remedies for unpaid wages through FWO. We begin by assessing the extent to which migrant workers seek FWO's assistance and the outcomes of those requests. We then consider the structural factors which contribute to migrant workers' reluctance to engage with FWO at all, followed by an examination of why wage recovery rates are low for migrant workers who do contact FWO. We explore the implications for individual remedies of FWO's strategic approaches to compliance, the difficulties that migrant workers encounter in contacting FWO and triggering the agency's direct intervention in practice, as well as the impact of evidentiary challenges. We conclude that although these challenges are numerous and multi-layered, they are not all inevitable and could be tackled through a new approach to reform in this area.

\section{Exploitation of migrant workers in Australia}

Exploitation of temporary migrant workers has been well-documented in Australia (Berg 2016, 96ff; Howe and Owens 2016). Reports of migrant workers enduring poor working conditions and other forms of abuse have steadily increased in Australia, with FWO reporting in 2016 that migrant workers feature in the worst examples of exploitation that it encounters (FWO 2016c, 1). Among 4065 migrant workers who participated in the TMW Survey, 30\% reported being paid $\mathrm{A} \$ 12$ or less per hour in their lowest paid job, with $45 \%$ paid $\mathrm{A} \$ 15$ or less (the current statutory minimum wage is $\mathrm{A} \$ 17.70$ per hour, and over $\mathrm{A} \$ 22$ per hour with casual rates). $74 \%$ believed that many, most or all migrant workers on the same temporary visa as them were paid less than the minimum wage.

This exploitation has occurred alongside a pronounced shift towards temporary migration which has eclipsed the historical pre-eminence of permanent settlement in this country. As of 30 June 2016, there were approximately 917,340 temporary visa-holders with work rights in Australia, excluding New Zealanders with unlimited work rights (DIBP 2016, 3). This includes 
three main groups of workers. First, international students may work up to 40 hours per fortnight while their course is in session and unlimited hours during breaks. As of 30 June 2016, there were 401,420 international students including partners in Australia. Second, working holiday makers - young travellers from certain countries with which Australia has a reciprocal relationship - may work up to six months with any one employer during their year-long stay in Australia. Third, skilled workers may work for a sponsoring employer, until March 2018 under the 457 visa. It is unknown how many international students, 457 visa-holders and working holiday makers are employed at any one time. However, based on estimated numbers, temporary visa-holders may comprise up to $11 \%$ of the Australian workforce (Senate Education and Employment References Committee 2016, 15).

Systematic underpayment of 457 visa-holders was recognised in a major government inquiry headed by Barbara Deegan in 2008, alongside other forms of exploitation and extortion by employers who used the threat of withdrawing sponsorship to achieve workers' compliance (Deegan 2008). However, in recent years, underpayments have become far more prevalent among international students (Reilly 2012, 181) and working holiday makers (Underhill and Rimmer 2015). As far back as 2005, a major empirical study found that $58 \%$ of working international students interviewed were earning less than the legal minimum wage (Nyland et al. 2009, 7). A more recent study by Clibborn found that of 1400 international students, $60 \%$ were paid below the federally mandated minimum wage (Bagshaw 2016).

The scale of un-remedied underpayment appears to be vast. 7-Eleven's internal wage repayment program alone is projected to repay $\mathrm{A} \$ 150$ million in unpaid wages to its mostly international student workforce (Ferguson and Danckert 2016). A migrant worker paid A\$12 per hour for 20 hours per week over six months would be owed at least $\mathrm{A} \$ 5267$, and this figure would be significantly higher if including higher weekend rates and other loadings and entitlements under the relevant Award. However, Australia has a long-standing culture of employer impunity for worker underpayment in which most incidences of underpayment are not detected or resolved (Goodwin and Maconachie 2007). The rise of temporary migration has occurred alongside dramatic deregulation of the labour market since the 1990s. Together, these shifts have arguably changed the Australian labour market, creating new opportunities for 
worker exploitation and new challenges for labour rights enforcement, including for FWO.

\section{Overview of current remedial mechanisms in Australia for underpaid workers}

Australia's industrial relations regulatory system is now largely contained in the Fair Work Act 2009 (Cth) (FW Act). Underpaid workers in Australia have three avenues for claiming unpaid entitlements, other than complaining directly to their employer. These are: first, unions or other advocates who can support direct approaches to employers; second, the courts, either with assistance from legal service-providers in the Federal Circuit Court of Australia (FCCA), or if self-represented, in the FCCA's small claims division or in local courts; or, third, they may seek FWO's assistance and intervention.

Australia's labour law enforcement and remedial mechanisms have been profoundly shaped by the central role played by unions throughout much of the twentieth century. With a legislative right of entry to workplaces and standing to seek recovery of wages and penalties in the courts, unions fulfilled numerous functions traditionally associated with an official enforcement agency. Indeed, prior to 1990, non-union members had no right to pursue legal action to enforce federal award provisions (Bray and MacNeill 2011, 157). However, labour relations regulation shifted away from union-based conciliation and arbitration during the 1990s, with successive legislative restrictions on unions' workplace activity. The resulting decline in union membership and heightened individualism in employment relationships (Landau et al. 2014,8 ) have inhibited unions' role in monitoring labour standards and individual claimsmaking (Landau and Howe 2016). While official regulatory agencies in Australia have traditionally been weak, an independent inspectorate was reinvigorated by the Howard Government in 2006 as part of the WorkChoices legislative reforms. A more prominent, 'independent' executive enforcement agency was established in the form of the Office of Workplace Services. Its labour inspectors were given stronger powers to investigate and new penalties to enforce employees' rights.

The current national labour inspectorate, FWO, was established under the FW Act in 2009. FWO uses a range of tools to promote cooperative workplace relations and ensure 
compliance with Australian workplace laws. These include providing information and education on work rights and obligations, receiving complaints, investigating suspected contraventions, and in a small number of cases, undertaking litigation and other enforcement actions against noncompliant employers. It has greater power, staffing, resources and political support than its predecessors to fulfil its enforcement role (Hardy 2009, 75), with wide powers to investigate breaches of Commonwealth workplace laws by visiting workplaces, interviewing people or requiring the production of documents. These powers were expanded by the Fair Work Amendment (Protecting Vulnerable Workers) Act 2017 (Cth). Despite the breadth of its mandate and activities, as of 2015, FWO had only 93 inspectors responsible for ensuring compliance with the FW Act nationally and 70 inspectors responsible for early intervention and alternative dispute resolution, serving more than 12 million workers in more than 2 million workplaces (Productivity Commission 2015, 1, 4).

With increasingly precarious work arrangements in Australia, and the entry of hundreds of thousands of young, temporary migrant workers into the low-wage labour market, there is a deepening need for remedial mechanisms that are accessible to individual temporary migrants. Workers in Australia currently primarily access remedies for unpaid wages through unions, the courts or FWO.

Although unions in some industries (such as meat-packing, horticulture and commercial cleaning) have proactively sought to recruit and represent temporary migrants with notable successes (Baker, McKenzie, and Schneiders 2016), temporary migrants are generally unlikely to proactively seek union assistance. Only $4 \%$ of respondents in the TMW Survey stated that they were union members, compared with approximately $9 \%$ in the general population (Hannan 2017).

The courts are similarly rarely utilised by migrant workers, primarily because they are inaccessible in practice. In an effort to increase the accessibility of certain civil remedy proceedings for individual plaintiffs, a small claims jurisdiction was introduced in the FCCA and Magistrates Courts in 2009 ( $F W$ Act, s 548). Although these procedures are more informal and 
not bound by formal rules of evidence, the complexity of applications creates prohibitive barriers for most temporary migrants. For example, a self-represented litigant must correctly identify the legal employer as well as the instrument the employer has breached, and prepare necessary affidavits and serve them on the respondents. These practical challenges are highlighted by the results of the TMW Survey: 1 in 12 participants (8\%) did not even know who paid their wages, let alone the correct name of the employer's formal legal entity. Affordable legal assistance for employment claims is highly limited (Legal Aid NSW Lawyer 2016, interview). In the context of an acute power imbalance in court between most temporary migrant workers and their employers, even those few employees who are able to file a claim have an understandably bleak view of the risks and likelihood of success (International Students Focus Group 2016).

This leaves FWO as the principal avenue through which temporary migrants may seek remedies for wage underpayment, even though the agency's core functions are not directed to the large-scale provision of individual remedies. Rather, FWO's resources are primarily oriented to strategic enforcement, systemic deterrence of non-compliance, and the promotion of harmonious workplaces. Recognising the vulnerabilities of migrant workers, the agency has made significant efforts in these areas to systemically address exploitative practices in relation to them.

\section{FWO's progress in detecting and deterring migrant worker exploitation}

FWO has expressed its determination 'to use every avenue in addressing exploitation of ... migrant workers', identifying the issue as one of the agency's two key priorities in 2015-2016 (FWO 2016c, 2). Migrant workers are now overrepresented in FWO's compliance and enforcement initiatives. FWO takes formal enforcement action in a limited number of cases in which it detects serious non-compliance with workplace laws. This takes four forms: infringement notices (similar to on-the-spot fines); compliance notices which require an employer to fix a contravention; enforceable undertakings (EUs) with employers that have accepted responsibility and agreed to remedy contraventions and ensure future compliance; and litigation seeking civil penalties, in approximately 50 of 'the most serious instances of noncompliance' each year (FWO 2015b, 34). In 2015-2016, FWO issued 222 more infringement notices than the previous year, which the agency attributed to its monitoring role 
concerning employer sponsors of 457 visa-holders (FWO 2016c, 21). Almost half (43\%) of FWO's 43 EUs established in 2015-2016 related to migrant workers (FWO 2016c, 22).

Previously, EUs were also established with Coles in relation to trolley collectors, in which the retailer agreed to back-pay 10 subcontracted workers $\mathrm{A} \$ 220,000$ and establish a $\mathrm{A} \$ 500,000$ fund to pay back others. Of the 50 litigations FWO commenced in 2015-2016, 76\% involved visaholders, a significant increase from $46 \%$ in the previous year (FWO 2016c, 1-2). FWO achieved record-breaking penalties in its 2015-2016 litigation against 7-Eleven franchisees and Woolworths trolley collection services (FWO 2016c, 22).

Ultimately, however, FWO recognises the limitations of selective enforcement actions as a deterrent to employers engaging in exploitative conduct. It has observed (James 2017b, 63):

While the system is fit-for-purpose to address accidental or negligent non-compliance, it has proven not to be fit-for-purpose when it comes to addressing the deliberate and systemic unlawfulness that some unscrupulous operators adopt as a business model. These operators ... consider the likelihood of being caught or the quantum of the penalties to be so low, that it is worth exploiting their workforce.

In light of these challenges, FWO has intensified its efforts to educate migrant workers and their employers about workplace rights and responsibilities. It has translated fact sheets and other materials into a significant number of community languages, and is deploying social media to direct migrant workers to its website. For example, during FWO's harvest trail campaign, visits to FWO website increased by $573 \%$, promoted by Facebook posts targeting working travellers and physical advertisements at regional airports (FWO 2016c, 14).

FWO has used a range of tools to detect and deter non-compliance in relation to migrant workers. These include investigations of specific workplaces where it suspects serious and deliberate non-compliance, or for general deterrence (FWO 2016a, 13, 16), as well as multi-year inquiries and campaigns which target systemic non-compliance in specific industries, supply chains, regions, or labour markets (FWO 2015b, 26, 31). In July 2012, FWO established an 
Overseas Workers Team of specialist inspectors, which co-ordinates targeted investigations in industries known to employ high numbers of visa-holders, such as hospitality, horticulture, poultry processing, cleaning, convenience stores and trolley collectors. Over the past two years FWO has conducted several extensive campaigns and inquiries into systemic non-compliance involving migrant workers. These have included inquiries into Baiada Poultry, the 7-Eleven franchise network, Woolworths trolley collection services, procurement of housekeepers by fourand-five-star hotel groups under the working holiday visa program, procurement of cleaners in Tasmanian Coles and Woolworths supermarkets, and the harvest trail which examines compliance in the fruit and vegetable growing industry.

Identifying the potential for 'fractured' employment relationships such as labour hire, sham contracting and other convoluted arrangements to undermine traditional labour protections, FWO has devised a regulatory strategy directed to encouraging responsibility within supply chains and franchises. In May 2017, the agency issued practical guides to assist businesses to monitor and manage their supply chains. This follows on from a number of FWO's investigations and inquiries that have resulted in compliance deeds with businesses at the head of a franchise or supply chain, which commit to remedy past breaches and prevent future contraventions.

\section{Individual migrant workers’' remedies through FWO}

These systemic initiatives to detect and deter migrant worker exploitation have been accompanied by an overall increase in wage recovery for migrant workers, rising from $\mathrm{A} \$ 1.1$ million in 2013-2014, to A \$1.6 million in 2014-2015, to A \$3 million in 2015-2016 (FWO 2016c, 1). Yet, despite the improvement in the overall amount that FWO is recovering, it appears that the recovery of unpaid wages overall remains limited. This section considers the extent to which migrant workers engage with FWO and the outcomes of their complaints to the agency, drawing on data supplied by FWO and from the TMW Survey.

Underpaid workers may come to FWO's attention through its proactive compliance activities or may directly contact FWO through its telephone Fair Work Infoline or its website. 
To formally seek FWO's assistance a migrant worker can submit a Request for Assistance (RFA). FWO may respond to informal complaints, RFAs or suspected noncompliance by, for example: helping the parties understand their rights, obligations and options; assisting them to settle the dispute; or undertaking an investigation and/or enforcement action. FWO has broad discretion as to how it responds, taking into account the seriousness of the alleged conduct, the circumstances of the parties, and practical issues involved in resolving the matter (FWO 2016a, 10). These include: the public interest; barriers faced by the complainant; whether the employer acted deliberately or was a repeat offender; whether there is sufficient information supporting the breach; parties' efforts to resolve the matter; whether the complainant wants the matter to remain confidential; significant monetary breaches, breach of minimum entitlements (prioritised over Award conditions); and whether the employment relationship has ended. More broadly, FWO's strategic priorities include the provision of information and advice and self-resolution of workplace issues (FWO 2015c).

Despite FWO's significant efforts to engage migrant workers, it appears that relatively few contact the agency through its Infoline or other means. Of the 2258 participants in the TMW Survey who recognised they had been underpaid, an overwhelming $91 \%$ had not tried to recover their unpaid wages through any means. Less than 3\% (62 individuals) contacted FWO. Nevertheless, migrant workers are over-represented among workers seeking FWO's assistance in general. Although only 1894 migrant workers submitted RFAs in 2015-2016, they comprised 13\% of all RFA complainants (FWO 2016c, 1), and 17\% for July - December 2016 (James 2017a, 79).

Survey data also suggest that a substantial number of those migrant workers who do contact the agency do not recover most or any of their unpaid wages. Of the 547 participants in the TMW Survey who knew someone who had approached FWO, almost half (47\%) of the claimants were unsuccessful in recovering their wages. Among the 62 participants who had contacted FWO themselves, 36 (58\%) recovered nothing, 13 (21\%) recovered some, and only 13 $(21 \%)$ recovered all of their unpaid wages. 
These low individual recovery rates accord with FWO data supplied to the authors recording the treatment paths applied to 2849 migrant worker RFAs resolved by the agency between 1 July 2014 and 31 December 2015. This data must be interpreted with caution for several reasons. For a start, terminology regarding treatment outcomes is broad and open to multiple interpretations. It is also possible that some worker remedies may not be recorded at all because FWO was not informed of outcomes after its role ended (for example, in mediation). More broadly, FWO has adopted a range of new systemic migrant worker initiatives since these RFAs were resolved, as described above.

Taking these caveats into account, the data suggest several broad trends. First, of the 2849 migrant worker RFAs resolved by FWO, at least 2495 (88\%) concerned wage issues. These included: non-payment of wages for time worked; underpayment of hourly rates; unauthorised deductions; unpaid trials; and non-payment of overtime and penalty rates. ${ }^{2}$ Second, only 341 (12\%) of these RFAs recorded a recovery of any wages and, of those, two in five (39\%) recovered $\mathrm{A} \$ 1000$ or less. Although data is unavailable on the amount of money these workers were seeking, it seems likely that most workers would have sought amounts substantially more than $\mathrm{A} \$ 1000$ to warrant the time, effort and risks involved in pursuing a remedy.

Third, almost half (45\%) of RFAs resulted in no further action by FWO and no recovery of wages. These included: 616 investigations terminated with no further action for reasons not supplied; 154 terminated because FWO could not contact the employer; 141 terminated because they were outside FWO's jurisdiction; 63 terminated because FWO did not identify a prima facie contravention; 52 terminated because of insufficient evidence; 37 terminated because the employer was no longer trading; ${ }^{3}$ and 16 terminated because allegations were not sustained. FWO terminated a further 165 RFAs because they were withdrawn by complainants. ${ }^{4}$ Forty-four RFAs were terminated after they went to mediation but could not be resolved. In addition to these RFAs that FWO did not pursue, a further 216 RFAs (8\%) were not pursued because they related to cases already subject to a FWO investigation.

\footnotetext{
2 This excludes RFAs concerning other matters such as allowances, annual leave, payment in lieu of notice, termination, sham contracting and superannuation.

3 Two of these workers nevertheless obtained monetary remedies.

4 Three of these workers nevertheless obtained monetary remedies.
} 
Fourth, where FWO used an approach such as mediation which focuses on voluntary inter-party resolution, very few migrant workers were recorded as obtaining remedies and where they did, the amounts were small. Of the 1138 RFAs (40\%) classified as resolved, 570 were through agreement between the parties via mediation, settlement, voluntary resolution or education. Within the 307 cases resolved via mediation, only three recorded recovery of money for workers, although it is possible that workers subsequently obtained money of which FWO was unaware. A further 263 cases involved settlement or voluntary resolution. ${ }^{5}$ Migrant workers obtained monetary remedies in approximately one-third (93) of those cases, however almost half of those (47\%) obtained less than A $\$ 1000$. A further 105 RFAs were resolved via 'education', presumably involving provision of information on rights and responsibilities. Monetary remedies were only recorded in three of those cases.

Fifth, in the limited cases in which FWO used compliance and enforcement measures, remedies were far more likely to be obtained, and often for greater amounts, than for RFAs resolved informally between the parties. This is consistent with FWO's general data from 20152016 which indicates that although enforcement actions on behalf of all workers reflected only $6 \%$ of finalised instances of noncompliance that year, they accounted for $30 \%$ of the total amount recovered for individual workers (FWO 2016c, 21). For example, of the 19 Compliance Notices issued, 13 resulted in monetary remedies. Eight of these workers recovered over $\mathrm{A} \$ 4000$, and one recovered $\mathrm{A} \$ 50,219$. This was also true for matters resolved by Voluntary Compliance (including EUs and proactive compliance deeds) or through issuing letters of caution. Of the 26 EUs, 16 involved monetary remedies for a total of 166 workers. ${ }^{6}$ Fourteen of those cases involved recovery of more than $\mathrm{A} \$ 6000$, and 10 involved more than $\mathrm{A} \$ 15,000$. Among the 146 RFAs resolved by Voluntary Compliance, workers recovered money in $78 \%$ of

\footnotetext{
${ }^{5}$ Sixty-eight cases settled prior to mediation with recovery of money for 21 workers; 12 investigations settled prior to a contravention finding with recovery of money for 4 workers; 48 cases were voluntarily resolved, with recovery of money for 10 workers; and Early Assisted Resolution in 147 cases, with recovery of money for workers in 58 cases.

${ }^{6}$ One EU concerned 46 workers, another 3 workers, and another 103 workers. Of those who did not recover, 8 cases involved unlawful deductions relating to what appears to be the same employer in farm work. Two were separate cases of underpayment of 417 visa-holders. EUs (unlike Compliance Notices) involve an admission that a contravention has taken place and a commitment to cooperate with FWO so, if the contravention relates to wage entitlements, you would expect a higher percentage result in remedies of back-pay.
} 
cases. However, almost half of these (46\%) recovered under A \$1000. Letters of Caution, putting an employer on notice that future breaches could result in FWO seeking financial penalties in court, also yielded somewhat better results than informal voluntary resolution. Although only 22 out of 59 such cases $(37 \%)$ resulted in remedies for workers, almost half (10 RFAs) resulted in monetary remedies over A $\$ 3000$. Among the 172 RFAs in which FWO completed investigations but took no further action, 1 in 5 (21\%) resulted in monetary outcomes for workers, suggesting that an investigation alone may encourage the employer to rectify their breaches in a small number of cases.

The following sections draw on interviews and other data to examine why so few RFAs are submitted in the face of widespread contraventions; why such a high proportion of these RFAs result in no wage recovery; and why so many resolutions involving wage recovery only secure A $\$ 1000$ or less - presumably substantially less than the migrant worker was seeking.

\section{Migrant workers' reluctance to engage with FWO}

According to FWO, temporary migrant workers are generally hesitant to come forward for assistance. This is especially the case for international students who are significantly underrepresented as a proportion of all visa-holders requesting assistance, despite their high level of exploitation (FWO 2016d, 46-48). This section examines four key sets of factors which may contribute to this reluctance: lack of knowledge of rights and awareness of FWO; migrant workers' attitudes regarding their rights and entitlement to make a claim; risks of losing employment; and fears of jeopardising immigration status.

A first set of barriers to engaging with FWO arises from workers' lack of knowledge of their rights or awareness of FWO itself. Many temporary migrant workers lack a detailed understanding of their entitlements (Hemingway 2016, 88; Kingsford Legal Centre Lawyer 2016, interview). However, results from the TMW Survey suggest that knowledge of basic rights may be higher: the vast majority of survey respondents (79\%) knew that minimum pay rates in Australia were at least $\mathrm{A} \$ 17$. What may be far more significant is migrants' lack of awareness of the existence of FWO, and lack of knowledge about how to engage FWO's practical assistance. 
In a recent study commissioned by FWO, only $26 \%$ of international student respondents were aware of FWO (Reilly et al. 2017, 6). Only 17\% of respondents to the TMW Survey knew someone who had tried to recover unpaid wages by contacting FWO. Of the 2061 respondents to the TMW Survey who had themselves been underpaid but had not tried to recover these wages, the most common reason given for not pursuing a wage claim was 'I don't know what to do' $(41 \%)$.

FWO is well aware of these barriers to engagement, and has made significant efforts in recent years to reach out to migrant workers. In 2015, FWO established a Migrant Worker Strategy and Engagement Branch to coordinate effective compliance, education and engagement activities for visa-holders. Recognising how little is known or understood about this oftenisolated workforce, the agency has also commissioned surveys and qualitative research on the views and motivations of working holiday makers (FWO 2016b) and international students (Reilly et al. 2017). In addition, FWO has promoted tailored resources to migrant workers through its website and via community groups. It has developed fact sheets and YouTube videos on working in Australia in up to 27 languages. The agency has also sought to engage with ethnic communities that employ large numbers of migrant workers. In January 2016 FWO launched its Chinese Australian Engagement Strategy, which was then followed by one with the Korean community, along with engagement with over 50 local councils (FWO 2016c, 5).

A second set of barriers relate to migrant workers' perceptions about their entitlements and the social implications of complaining. For example, some workers reported that they would not complain because many people around them were being paid similarly and they were not complaining (25\%), or because they would feel embarrassed or ashamed if they came forward (11\%). Thirty-five per cent of respondents believed they should not complain because they had agreed to the wage. Seven per cent stated they would not complain because they were going home soon. However, it appears that when migrant workers engage FWO's assistance while in Australia, the agency can in fact maintain claims on the worker's behalf once he or she has returned home (Fair Work Ombudsman 2015d). 
A third key inhibitor to engagement is the prospect that complaining to FWO about unpaid wages may trigger loss of employment, which occurred in a number of cases identified by migrant worker and union informants (Migrant Worker 2016, interview; AMIEU NSW Representative 2016, interview). Lacking social security entitlements, unemployment may be devastating for temporary workers, particularly those who depend on their employment income for daily survival and believe that they will be unable to find another job. Discrimination at the point of entry into the labour market may further contribute to "willingness to accept inferior working conditions' (Tham 2016, 9-10). Moreover, the fact that some temporary workers find employment from within their same ethnic communities can generate fears that a complaint may be portrayed negatively within their community, narrowing future job options (Korean Workers Focus Group 2016). Indeed, 25\% of respondents to the TMW Survey reported that they found their lowest paid job through a friend or family member. However, beyond these general factors, fear of job loss is especially potent for two groups of workers who tend to reside in Australia over the longer term. The first, international students, have often made substantial financial, social and other investments to complete their studies in Australia, which are funded by ongoing employment. For the second group of workers, 457 visa-holders, loss of employment can directly trigger visa cancellation unless another sponsoring employer can be found within 60 days.

The final significant barrier to approaching FWO is workers' immigration-related fears about jeopardising their ongoing stay in Australia, because FWO has legislative authority to refer evidence of unlawful activity to the DIBP ( $F W A c t$, s 682(e)). These fears may be particularly acute for international students who are permitted to work no more than 40 hours work per fortnight while their course is in session. Work in excess of that limitation constitutes a discretionary ground for visa cancellation by the DIBP and removal from Australia (Migration Act 1958 (Cth), s 116(3)). Immigration-related fears are also significant for 457 visa-holders because FWO is tasked with monitoring compliance of their sponsoring employers, and detection of sponsorship breaches (including underpayment) can trigger visa cancellation.

The agency is aware of these concerns and does not require complainants to disclose their immigration status and it does not routinely refer international student visa breaches to the DIBP (James 2017a, 79). Indeed, in a number of cases FWO has proactively sought DIBP assurances 
against visa cancellation in order to facilitate visa-holders' engagement with the regulator and potential court action (Unite Organiser 2016, interview). Nevertheless, the unpredictability of FWO's discretion to seek leniency from the DIBP has led some legal service providers to recommend migrant workers to not contact FWO where work has been undertaken in breach of visa conditions (Community Legal Centre Representative 2016, interview). Even a remote possibility of removal in the middle of a student's studies profoundly shapes their behaviour (International Students Focus Group 2016; Community Legal Centre Representative 2016, interview; JobWatch Representative 2016, interview). Some are similarly deterred by the possibility that a complaint will trigger the detection of co-workers who may be working in breach of visa conditions (Migrant Worker 2016, interview). Workers who are paid in cash are also fearful that approaching FWO will disclose an unpaid tax liability, which in turn could have financial and immigration consequences (International Students Focus Group 2016).

In mid-2017, FWO and DIBP publicised a new protocol stating that a worker's temporary visa will not be cancelled if the worker reports exploitation and is actively assisting FWO in an investigation. ${ }^{7}$ It applies as long as the worker holds a temporary visa with work rights, they commit to abide by visa conditions in the future and there is there is no other basis for visa cancellation. This certainly reflects a significant step towards protecting temporary migrants with work rights and FWO has actively promoted this initiative to service-providers and workers themselves. However, it does not establish a firewall between the FWO and the DIBP such that the FWO can guarantee the confidentiality of information provided by migrant workers requesting assistance. To the contrary, it requires that FWO notify DIBP of the migrant worker's visa status to obtain the visa cancellation dispensation, and it does not appear to give rise to any right on the part of a visa-holder to appeal a visa cancellation on the basis of unauthorised work. The dispensation is also conditional on FWO's assessment as to the whether the individual is actively assisting FWO and it is unclear whether the dispensation could be withheld or revoked if the migrant worker does not wish to participate or continue participating in an investigation, or if FWO declines to pursue the matter further. It remains unclear whether the protocol will offer sufficient comfort to enable visa-holders with work rights to come forward and report

\footnotetext{
${ }^{7}$ Fair Work Ombudsman, Visa Holders \& Migrants < https://www.fairwork.gov.au/find-help-for/visaholders-and-migrants $>$.
} 
exploitation.

In a parallel effort to address immigration-related and other concerns that inhibit engagement, FWO also introduced an online Anonymous Report tool in April 2016. The tool allows workers to provide information or to share concerns about a workplace without identifying themselves, generating intelligence for FWO. By the end of December 2016, 6500 anonymous reports had been lodged, $14 \%$ of which were from migrant workers. In 2017, as part of its involvement with the Migrant Workers' Taskforce, this tool was slated to be redesigned specifically for migrant workers, including translations into 15 languages (O'Shea 2017, 78).

FWO has also made various policy decisions to encourage engagement by temporary migrants who have worked in breach of their visa conditions, including international students who have worked more than 40 hours per fortnight. For example, FWO adopts an expansive interpretation of the legal protections of work that is not authorised by workers' visas and prohibited by the Migration Act. Concerningly, some legal precedent suggests that under these circumstances, the employment contract is invalid and therefore the worker cannot recover unpaid wages (Berg 2016, 170; Clibborn 2015, 1). However, FWO has publicly taken the view that FW Act entitlements are enjoyed by all employees (FWO 2015a, 3) and has brought a number of successful enforcement proceedings where migrant workers have breached their visa conditions.

Against the backdrop of these formidable structural barriers which, as FWO acknowledges, discourage migrant workers from seeking assistance to recover underpayments, the following section examines the challenges in addressing underpayments for those who do submit wage claims.

\section{Why are wage recovery rates low for migrant workers who contact FWO?}

A number of factors contribute to migrant workers' low wage recovery rates through FWO. FWO's overall strategic approaches prioritise other regulatory objectives over individual remedies. As a result, migrant workers can encounter challenges in contacting FWO as well as 
challenges in triggering direct intervention by FWO once assistance has been sought. A lack of evidence and high burden of proof also impede migrant workers' ability to pursue successful wage claims. Each of these factors is examined below.

\section{FWO's strategic approaches to compliance}

There are three components to FWO's approach to its compliance and enforcement activities which serve important functions and are justified by valuable regulatory strategies, but which may ultimately de-prioritise or impede individual migrant workers' access to remedies.

First, FWO seeks to proactively detect contraventions within certain high-risk industries

and vulnerable labour forces, rather than reactively engaging in enforcement actions triggered by individual complaints. This approach accords with a number of recommended regulatory responses to systemic labour contraventions which involve vulnerable workers in particular, as it removes the onus on vulnerable workers coming forward themselves (Weil 2010) and discourages the individualisation of enforcement of rights and entitlements (Cockfield et al. 2011, 135).

Second, FWO's statutory objects adopt a mix of persuasive, reforming and deterrent sanctions to address drivers of non-compliance, rather than a command-and-control approach focused on full technical legal accountability for past wrongs (Hardy, Howe, and Cooney 2013, 567). Although remedies for workers may flow from these activities or be a means to achieving their goals, they are not a primary objective in their own right. Consistent with this approach, FWO conducts investigations and uses enforcement actions (and penalties) in only a limited number of cases, generally to maximise deterrence (Howe and Hardy 2017), and after substantial opportunities for the employer to voluntarily rectify contraventions. FWO also targets structural and behavioural drivers of non-compliance to influence 'price makers' such as head contractors in supply chains (FWO 2015a). As a former head of the agency observed (Wilson 2012, 8):

Our inspectors cannot be in every pay packet nor every workplace, so by necessity, we operate on a voluntary compliance model, which is much easier to achieve if there is a broad industry 
acceptance of the over-arching policy and our role.

At the same time, he observed that litigation remains a central strategy, because 'the only way you can [achieve voluntary compliance] is because there is an explicit threat as to what will occur if you don't comply' (quoted in Johnstone and Parker 2010, 66).

This strategic, persuasive and proactive enforcement approach clearly serves important functions. However, absent other accessible remedial mechanisms, it leaves large numbers of temporary migrants and other vulnerable workers without paths to redress.

This may be especially the case in light of the third component of FWO's approach, namely its commitment, since 2014, to 'encourage and empower parties to self-resolve' (Jones 2015). This has two dimensions. The first is prioritising the preservation of employment relationships through amicable dispute resolution. FWO is tasked, among other things, with promoting 'harmonious, productive and cooperative workplace relations' (FW Act, s 682(1)(a)). While FWO's primary focus when it was first established was to commence an investigation into all worker complaints, it has more recently determined that Australia's 'complex workplace relations framework demands greater focus on Alternative Dispute Resolution processes' (James 2017c, 3). The second dimension is the agency's focus on self-help, which seeks to inform, equip and empower workers so that they can effectively address workplace issues themselves.

For temporary migrant workers, however, preserving employment relationships and selfhelp seem ill-suited to the context of their low-wage employment. By definition, these workers' employment relationships are temporary and rarely involve aspirations for long-term career progression. Moreover, many temporary workers are unlikely to retain their employment relationships if they complain; they are effectively dispensable in the saturated labour market of their low-wage industries. At the same time, few temporary migrants are able to engage in selfhelp strategies for the reasons set out above regarding their reluctance to complain at all. Language, cultural and other structural barriers impede migrant workers' ability to navigate information sources or articulate and pursue formal claims in any forum. Furthermore, the 
pronounced power disparity between migrant workers and their employers leaves them at a severe disadvantage in direct negotiations or even formal mediation.

Along with other challenges, these features of FWO's overall strategic orientation can shape the way migrant workers engage with FWO and how it responds, including the difficulties they may encounter when contacting FWO and triggering its intervention.

\section{Challenges in contacting $F W O$}

In accordance with FWO's self-help approach to dispute resolution, both its Infoline and website prioritise the provision of information on workplace rights. According to a FWO representative (Reilly et al. 2017, 66):

\footnotetext{
We are trying to encourage customers to seek the information themselves first. One of our strategic goals is to ... empower those employees and employers to get the right information and then try and resolve it themselves in the workplace.
}

However, given that few migrant workers are in a position to engage in self-help, they are more likely to be accessing FWO's website to seek direct assistance and intervention - functions which the website does not appear to be designed to easily facilitate. The website's 'online assistance request form' is challenging to find, particularly for non-English speakers, and only available in English. There is evidence that international students have struggled to access information on the website about how to contact FWO (Reilly et al. 2017, 67). Moreover, in order to submit a claim to which FWO responds, a worker must create an account with FWO, which many temporary workers are fearful of doing (7). Alternatively, workers can use the Anonymous Report tool. However, this appears to be unappealing to migrant workers because FWO does not respond and uses the complaint for intelligence purposes only (7). Although migrant workers may prefer to contact FWO via its Infoline rather than its website (68), the telephone is also challenging for non-English speakers, despite FWO's free interpretation services (International Students Focus Group 2016). Indeed, among the 2061 respondents in the Temporary Visa Holder Survey who had been underpaid but had not tried to recover these 
wages, $34 \%$ stated a reason for this was that 'It's too much work', with $20 \%$ stating 'The forms are too complicated' and 15\% stating 'My English isn't good enough'.

\section{Challenges in triggering direct intervention by FWO}

The vast majority of individuals who contact FWO's Infoline are provided with information or are referred to other avenues for pursuing help, and receive no further assistance at that point. Indeed, the agency has a target of resolving $80 \%$ of calls to its Infoline at first contact (FWO 2015b, 3). It achieved 'resolution' in an overwhelming 98\% of calls at first contact in 2015-2016 (FWO 2016c, 9). Most of the remainder would have been encouraged to submit a formal RFA or received early intervention advice and assistance measures such as education about their options and providing resources (FWO 2016c, 10, 17; 2015b, 21). One of the agency's key performance targets is that 'at least $90 \%$ of requests for assistance involving a workplace dispute are finalised through education and dispute resolution services' and not through enforcement and compliance activities (Department of Employment 2016, 130).

In some cases, FWO recommends claimants file small claims in court, and provides limited assistance to do so (in 2014-2015, for approximately 1000 individuals (FWO 2015b, 24)). This generally involves clarifying the small claims process, directing the worker to resources such as court websites and FWO's guide to small claims. For a small number of 'individuals who face barriers to taking action', FWO may help the worker to complete court application documents or advise the worker on how to gather evidence or serve court documents (FWO 2016a, 18). In cases in which an employer disputes FWO's jurisdiction (for example, by falsely asserting the arrangement is a contract for service rather than a relationship of employment), FWO may advise the worker to resolve the issue in court. This arose, for example, when two Korean backpackers had lodged an RFA but were told that FWO would not provide assistance because 'there appears to be a difference in interpretation by your employer in relation to the matters raised' that needed to be tested in court. The Fair Work Inspector gave the workers an estimate of wage rates, a copy of the Award, and a small claims guide (Korean Worker 2016, interview). 
In circumstances where an entity other than the employer might be a source of remedies, a worker may be directed to approach that entity instead of FWO. For example, in one case where a Domino's employee reported an underpayment to FWO, they were referred to Domino's head office to 'work with the franchise to deal with that'. In explaining this approach, a FWO compliance official stated (James 2017a, 63):

\begin{abstract}
What we are trying to do is engender a culture of compliance across a network of operations, in this case Domino's. Our view is that large corporations like this should not have the benefit of a taxpayers' regulator to clean up these issues. We think that is an obligation that the operation and the franchise should have. We are giving them first chance at dealing with these issues. The individual claimant always has the ability to come to us with their concern about how that has been dealt with or raise the concern that they do not want us to refer this issue to Domino's.
\end{abstract}

In some cases, it seems that migrant workers do not or cannot articulate their claim or issues comprehensively or clearly enough to initiate FWO's intervention. In the experience of one community legal centre (CLC), FWO does not provide workers with assistance to ventilate their claims and only pursues cases once issues are already correctly identified and evidenced (Hemingway 2016, 129). The CLC reports that particularly vulnerable workers frequently require ongoing assistance to articulate their claim to FWO and effectively engage in any subsequent FWO investigations or mediations.

Although there is a widespread view that legal services are critical for newly arrived migrants to assert their workplace rights in Australia (Footscray Community Legal Centre 2015, 7-9), legal services for employment matters are scarce and unavailable to most migrant workers. This can impede access to FWO in the first instance. It also creates hurdles for workers calculating their unpaid wages and entitlements, which requires significant time, a fair degree of mathematical skills, as well as knowledge of the appropriate Award classification, base rate of pay, and other rates applicable at different times (Federation of Community Legal Centres Victoria 2014, 10). For numerous CLCs and private firms, the sheer resource intensiveness of this process is one of the greatest obstacles in representing temporary migrants to recover their unpaid entitlements. FWO does provide a Pay and Conditions Tool (PACT) on its website which 
is intended to enable workers to determine their rate of pay (including penalty rates). However, this tool does not assist workers to determine the actual amount owing, and may be difficult to use for those who are unable to identify their precise job classification. FWO no doubt devotes resources to determine the amounts owed to workers whose claims fall within a broader investigation, campaign or because they are progressed by FWO for other reasons. However, for the vast majority of workers, insufficient assistance is available.

FWO has recently recognised this problem and has targeted the availability of affordable legal services for migrant workers. In 2017, a remodelled program for funding community-based employment advice services, the Community Engagement Grants Program, awarded A \$7.3 million over four years to fund various initiatives across the country. For the first time, these grants prioritised services for migrant workers because, in the words of Ombudsman Natalie James $(2017$ a, 66), 'we know that migrant workers are loathe to come to government for help. Often intermediaries are better positioned than we are to work on that issue'. However, this funding is unlikely to be sufficient given the magnitude of the need.

Finally, FWO's typical forms of intervention which seek to promote its commitment to self-help and amicable dispute resolution, may be inappropriate for many low-waged migrant workers. These include mediation, which involves an accredited FWO mediator giving the parties an opportunity to find mutually acceptable solutions, although outcomes are not enforceable and FWO cannot compel an employer to attend. In 2015-2016, FWO resolved around half (7343) of RFAs through education and various methods of alternative dispute resolution. Only 1 in 10 of these resolutions involved recovery of unpaid wages, although it is possible that a portion were seeking non-monetary remedies (FWO 2016c, 18). Mediation is unlikely to achieve just outcomes for migrant workers because of the power disparity between them and their employers, especially in a context where underpayment is often knowing and deliberate and given migrant workers' particular vulnerabilities. Temporary migrant workers are therefore often looking for an advocate or arbitrator, roles which are not provided in this treatment path, leading some workers to conclude that FWO does not 'have any teeth; they can't enforce things' (International Students Focus Group 2016). Indeed, FWO generally considers cases involving exploitation and serious non-compliance to be unamenable to mediation (FWO 
2016c, 18), even though it used mediation in approximately 1 in 10 cases involving migrant workers in the 18-month period in FWO-supplied data.

\section{Evidentiary challenges}

A further barrier preventing temporary migrants from pursuing wage claims is the widespread lack of evidence such as payslips or other proof of wages paid and hours worked. Over two-fifths of participants in the TMW Survey (42\%) reported that they were paid in cash in their lowest paid job, and just under half (49\%) reported that they received payslips rarely or never. For those whose employers do issue payslips or hold records, these are commonly fabricated (Productivity Commission 2015, 927). Legal service providers also find that the evidence temporary migrants present is 'very, very often ... incomplete' (Legal Aid NSW Lawyer 2016, interview).

Record-keeping contraventions constitute a large portion of FWO's litigation. In many of these matters FWO is unable to calculate the quantum of underpayment due to lack of records, resulting in workers not obtaining a remedy. In 2015-2016, 26 out of 50 litigations filed involved alleged record-keeping contraventions and in 16 cases (62\%) involving 265 workers, FWO could not calculate underpayments owing (FWO, 2017). In one case, a blueberry farmer kept rough records recording approximately A $\$ 12$ hourly wages to 60 backpackers identified only by their first name. The Court fined the employer $A \$ 13,005$ for record-keeping contraventions but did not order remedies for the underpaid workers because it was 'impossible to calculate the precise quantum of the underpayments' (Fair Work Ombudsman v Dosanjh [2016], at [35]).

FWO performs an evidence-gathering role in a small number of cases. In these cases, FWO Inspectors do a great deal to reconstruct workers' records. This includes accessing CCTV footage, cash register log-in records, public transport records, text messages and security logs. However, as Natalie James has observed, '[u]nless workers have meticulously kept their own records of their hours of work, it becomes very difficult to assess whether underpayments have arisen' (James 2017c). In general, the agency appears to have been unwilling to draw inferences 
in employees' favour in the absence of clear physical evidence. A number of informants have suggested that if FWO is presented with any evidence by employers which on its face contradicts the worker's claim, it has been unlikely to proceed with a fuller investigation in the absence of a critical mass of workers (Australian Law Firm Lawyer 2016, interview; Community Legal Centre Representative 2016, interview). Indeed, where evidence is disputed, FWO may suggest workers resolve their complaints on their own through a small claims procedure (FWO 2016a, 14). In explaining why it was unable to progress many of the claims of underpaid 7-Eleven employees, FWO has stated that '[w]here alternative evidence is limited or unavailable, we are restricted in our capacity to investigate' (FWO 2016d, 19). In another case, a private firm representing a victim of labour trafficking approached FWO to investigate the worker's claim for more than $\mathrm{A} \$ 5000$ in unpaid annual leave entitlements. FWO declined to progress its investigation because the employer (who had pled guilty in the criminal matter) produced records which purported to document that the relevant payments had been made (Australian Law Firm Lawyer 2016, interview). The firm later successfully pursued a civil claim for A $\$ 186,000$ in underpayments.

FWO's reluctance to draw inference in workers' favour in the absence of clear evidence of a contravention has reflected the approach taken by courts to date. However, the Fair Work Amendment (Protecting Vulnerable Workers) Act 2017 (Cth) now mandates that, in relation to certain civil remedy provision, where the employer failed to issue payslips, the employer bears the burden of disproving the worker's allegation (s557C, Fair Work Act 2009 (Cth)). It is unclear whether FWO will adopt a similar presumption in its own investigatory practices.

FWO has recognised the significant impediment created by lack of evidence and the prevalence of cash wage payments in certain industries (FWO 2016b). In addition to its enforcement activities, FWO has taken an innovative and proactive approach in developing an evidence-generating smartphone app. The app enables workers to document their hours and verify their location at a worksite using GPS technology. Introduced in March 2017, Record My Hours had been downloaded nearly 9000 times by May (FWO, 2017), suggesting it has been well-publicised and offers promise in addressing evidentiary obstacles. 


\section{Conclusion}

FWO is operating in an extraordinarily challenging industrial landscape, with limited resources and a far-reaching mandate. It is tasked with fostering compliance across diverse industries (such as horticulture and hospitality) riven by informal work practices and endemic noncompliance, and a labour force which has transformed in recent decades with the entry of hundreds of thousands of international students and backpackers. These workers are often isolated and not willing to contact, or be contacted by, government agencies. Indeed, until recently there has been limited public awareness of, and little official action on, the systemic exploitation of these workers.

Amid these formidable obstacles, FWO has stepped into the breach and undertaken a range of significant and often innovative initiatives to understand and improve conditions for migrant workers. FWO's broader education, compliance and deterrence initiatives reflect a widely-supported, strategic use of limited resources to make important inroads in preventing exploitation in the medium to long term. FWO's enforcement actions have focused disproportionately on migrant workers, recovering A \$5.7 million in unpaid wages between 2013 and 2016.

At the same time, FWO processes are not designed to secure individual remedies for the tens or hundreds of thousands of exploited migrant workers who are each owed many thousands of dollars. This is partly the result of FWO's strategic focus on self-help and employment preservation. This results in some workers who approach FWO being provided only with information on workplace rights or worker options, or being referred to other avenues for dispute resolution, or even FWO-facilitated mediation - avenues that are unlikely to yield effective outcomes. In 2014-2015, a migrant worker who lodged an RFA had a 1 in 10 chance of recovering their wages, with a $40 \%$ chance they would recover less than $\mathrm{A} \$ 1000$.

When the likelihood and quantum of a successful outcome are weighed against the time, effort, costs and risks to immigration and/or employment status, it appears rational that 
individual migrant workers are not seeking remedies even if they are being significantly underpaid. In the absence of broader union membership or reinvigorated judicial or other redress pathways that are accessible, effective individual remedies remain beyond the reach of most exploited migrant workers in Australia.

Reform efforts must therefore be broadened beyond longer-term prevention of exploitation - as essential as this - to also ensuring that individual migrant workers can access remedies to recover their wages. In order to be effective, these efforts must work to reduce the costs and risks of bringing a complaint, and increase the benefit and likelihood of obtaining a remedy. One way of reducing risks to the worker is to create a firewall between the FWO and DIBP to ensure that workers' immigration status remains confidential. The 2017 protocol between FWO and DIBP may go some way to achieving this end. Another way is to reduce the time and effort involved in bringing a claim. For example, FWO's website and Infoline could be designed to more expeditiously link migrant workers to FWO's assistance, rather than primarily focus on providing information.

To increase the likelihood that a migrant worker who makes a claim will recover a significant portion of his or her unpaid wages, resources should be devoted to providing legal representation and other assistance to help identify and substantiate all potential claims and explicitly advocate on the worker's behalf. Reform efforts should consider whether current judicial and FWO processes are suited to, and capable of, delivering remedies to large numbers of individual unpaid workers, or whether alternative or modified claims-handling forums should be explored. In the meantime, FWO's strategic priorities could be modified to promote not only rates of case resolution and systemic enforcement actions, but also recovery of unpaid wages for individual workers as a target and metric of success that is tracked for each individual RFA - independent of the broader goal of building a future culture of compliance. FWO should also consider adopting a presumption in favour of the migrant worker rather than the current presumption in favour of the employer, especially in cases of missing or falsified employment records and payslips. This is necessary to account for evidentiary hurdles that are often the result of exploitation in the first place, and would accord with the new reverse onus of proof introduced by the Fair Work Amendment (Protecting Vulnerable Workers) Act 2017 (Cth). 
In its reform efforts to secure migrant workers' work rights and prevent exploitation, the Australian government must ensure that migrant workers can practically access remedies for rights violations. Providing information about workplace rights is not sufficient to meaningfully improve migrant workers' access to remedies. What is required is a migrant-centred and migrantinformed approach that appreciates that migrant workers are rational actors who will more likely pursue remedies when they are accessible and the risks and costs are outweighed by the propsect of obtaining a just outcome.

\section{Disclosure statement}

No potential conflict of interest was reported by the authors.

\section{Notes on contributors}

Laurie Berg is a Senior Lecturer at the University of Technology Sydney. Her research focuses on immigration and labour law, immigration and domestic work, and sexual orientation and gender identity in the context of asylum determinations. Her current research projects include: Transformative Technology for Migrant Workers, Forced Labour and Temporary Labour Migration in Australia, International Students and the Fair Work Ombudsman; and When a Worker is Not a Worker: The Contradictions of Au Pairing in Australia.

Bassina Farbenblum is a Senior Lecturer at the University of New South Wales. Her research focuses on labour migration and the human rights of migrant workers, with a particular focus on Asia and Australia. She is the director of the Australian Human Rights Centre's Migrant and Refugee Rights Project, and the director of UNSW's Human Rights Clinic. She has practised as a human rights litigator and clinical legal educator in New York, Mumbai, and Sydney. Her recent and current research projects focus on migrant workers' access to justice in countries of origin; governance of migrant worker recruitment; transformative technology for migrant workers; and migrant workers' access to justice in Australia. 



\section{References}

Australian case law

Fair Work Ombudsman v Dosanjh [2016] FCCA 923

\section{Australian legislation}

Migration Act 1958 (Cth)

Fair Work Act 2009 (Cth)

Fair Work Amendment (Protecting Vulnerable Workers) Act 2017 (Cth)

\section{Other references}

AMIEU NSW Representative (2016) personal communication, 27 January

Arup C and Sutherland C (2009) 'The recovery of wages: legal services and access to justice' 35 Monash Law Review 96

Australian Law Firm Lawyer (2016) personal communication, 29 February

Bagshaw E (2016) ' 80 per cent of international students in restaurants paid below minimum wages, survey finds' Sydney Morning Herald 21 April [Online] Available

<www.smh.com.au/national/education/80-per-cent-of-international-students-in-restaurants-paidbelow-minimum-wage-survey-finds-20160421-gobkzh.html> [2017, May 20]

Baker R, McKenzie N and Schneiders B (2016) 'Another supermarket fruit supplier caught allegedly underpaying migrants' Sydney Morning Herald 15 November [Online] Available <www.smh.com.au/business/workplace-relations/another-supermarket-fruit-supplier-caughtallegedly-underpaying-migrants-20161115-gspu0v.html> [2017, May 20] 
Berg L (2016) Migrant Rights at Work: Law's Precariousness at the Intersection of Immigration and Labour Routledge, Oxon/New York

Berg L and Farbenblum B (forthcoming) 'Remedies for Unauthorised Migrant Work in Australia: An Empirical Study Comparing Doctrine and Practice' in B Ryan (ed), Migration and Employment Law in Comparative Perspective Hart, forthcoming

Bray M and MacNeill J (2011) 'Individualism, collectivism and the case of awards in Australia' 53 Journal of Industrial Relations 149

Campbell I, Boese M and Tham J-C (2016) 'Inhospitable workplaces? International students and paid work in food services' 51 Australian Journal of Social Issues 279

Clibborn S (2015) 'Why undocumented immigrant workers should have workplace rights' 26(3) The Economic and Labour Relations Review 1

Cockfield S, Buttigieg D, Jerrard M, Rainnie A (2011) 'Assessing the impact of employment regulation on the low-paid in Victoria' 22(2) The Economic and Labour Relations Review 131 Community Legal Centre Representative (2016) personal communication, 30 March

Deegan B (2008) Visa Subclass 457 Integrity Review: Final Report, Commonwealth of Australia Department of Employment (2016) Portfolio Budget Statement for the Fair Work Ombudsman: Entity Resources and Planned Performance

Department of Immigration and Border Protection (2016) Temporary Entrants and New Zealand Citizens in Australia: As at 30 June 2016 
Ferguson A and Danckert S (2016) '7-Eleven clamped by Fair Work Ombudsman in new "landmark" deed' Sydney Morning Herald 7 December [Online] Available <www.smh.com.au/business/retail/7eleven-clamped-by-fair-work-ombudsman-in-newlandmark-deed-20161206-gt5irm.html> [2017, May 25]

Fair Work Ombudsman (nd) Strategic Intent Available < https://www.fairwork.gov.au/aboutus/our-vision/strategic-intent>

Fair Work Ombudsman (2013) Litigation Policy of the Office of the Fair Work Ombudsman, Guidance Note 1, 4th edn

Fair Work Ombudsman (2015a) Submission No 368 to the Productivity Commission, Inquiry into the Workplace Relations Framework, 18 September

Fair Work Ombudsman (2015b) 2014-15 Fair Work Ombudsman Annual Report

Fair Work Ombudsman (2015c) Corporate Plan 2015-19 Available <https://www.fairwork.gov.au/about-us/our-vision/corporate-plan>

Fair Work Ombudsman (2015d) 'Back-payment bill for Sydney café operators after Korean workers short-changed almost \$40,000’ Media Release, 1 October [Online] Available <www.fairwork.gov.au/about-us/news-and-media-releases/2015-media-releases/october2015/20151001-marsil-eu-presser> [2017, May 20]

Fair Work Ombudsman (2016a) Compliance and Enforcement Policy, Commonwealth of Australia

Fair Work Ombudsman (2016b) Inquiry into the Wages and Conditions of People Working Under the 417 Working Holiday Visa Program, Commonwealth of Australia 
Fair Work Ombudsman (2016c) 2015-16 Fair Work Ombudsman Annual Report

Fair Work Ombudsman (2016d) A Report of the Fair Work Ombudsman's Inquiry into 7-Eleven: Identifying and Addressing the Drivers of Non-Compliance in the 7-Eleven Network

Fair Work Ombudsman (2017) 'Low penalties mean workers pay for dodgy record keeping' Media Release, 2 May [Online] Available <www.fairwork.gov.au/about-us/news-and-mediareleases/2017-media-releases/may-2017/20170502-aig-2017-speech> [2017, May 20]

Fair Work Ombudsman Senior Officials (2016) personal communication, 19 July

Federation of Community Legal Centres, Victoria (2014) Putting the Law to Work: Meeting the Demand for Employment Law Assistance in Victoria

Footscray Community Legal Centre (2015) Submission No 143 to Productivity Commission, Inquiry into Australia's Workplace Relations Framework, 12 March

Goodwin M and Maconachie G (2007) 'Unpaid entitlement recovery in the federal industrial relations system: strategy and outcomes 1952-95'49 Journal of Industrial Relations 523

Hannan E (2017) 'Union membership hits record low' The Australian 4 May [Online] Available <www.theaustralian.com.au/national-affairs/industrial-relations/union-membership-hits-recordlow/news-story/489e5ba953baaf345bf5f4d851067223> [2017, May 20]

Hardy T (2009) 'A changing of the guard: enforcement of workplace relations laws since work choices and beyond', in Forsyth A and Stewart A (eds) Fair Work: The New Workplace Laws and the Work Choices Legacy Federation Press, Sydney pp 75-98 
Hardy T, Howe J and Cooney S (2013) 'Less energetic but more enlightened? Exploring the Fair Work Ombudsman's use of litigation in regulatory enforcement' 35 Sydney Law Review 566

Hemingway C (2016) Not Just Work: Ending the Exploitation of Refugee and Migrant Workers WEstjustice Employment Law Project, Final Report

Howe J (2016) 'Regulation of Australia's labour migration program: Is there a case for including fairness?' 29 Australian Journal of Labour Law 58

Howe J and Hardy T (2017) Business Responses to Fair Work Ombudsman Compliance Activities: Research Report, Centre for Employment and Labour Relations Law, Melbourne Law School

Howe J and Owens R (eds) (2016) Temporary Labour Migration in the Global Era: The Regulatory Challenges, Bloomsbury Publishing Plc, Oxford/Portland

International Students Focus Group (2016) personal communication, 13 October

James N (2017a) Evidence to Education and Employment Legislation Committee, Senate, Canberra, 2 March

James N (2017b) Evidence to Education and Employment Legislation Committee, Senate, Canberra, 12 April

James N (2017c) 'Current Issues in the Regulation of Australian Workplaces', Speech delivered at Australian Industry Group Annual National Policy-Influence-Reform Conference, 1 May

JobWatch Representative (2016) personal communication, 30 March 
Johnstone R and Parker C (2010) Enforceable Undertakings in Action: Report of a Roundtable Discussion with Australian Regulators, Working Paper No 71, National Research Centre for Occupational Health and Safety

Jones A (2015) 'Rights and Responsibilities Under the Fair Work Act 2009', Paper presented to the Western Australia Local Government Association, 7 August

Kingsford Legal Centre Lawyer (2016) personal communication, 5 February

Korean Worker (2016) personal communication, 22 November

Korean Workers Focus Group (2016) personal communication, 21 March

Landau I and Howe J (2016) 'Trade union ambivalence toward enforcement of employment standards as an organizing strategy' 17 Theoretical Inquiries in Law 201

Landau I, Cooney S, Hardy T and Howe J (2014) Trade Unions and the Enforcement of Minimum Employment Standards in Australia: Research Report, Centre for Employment \& Labour Relations Law, Melbourne Law School

Legal Aid NSW Lawyer (2016) personal communication, 8 February

Migrant Worker (2016) personal communication, 29 April

Nyland C, Forbes-Mewett Helen, Marginson S, Ramia G, Sawir E and Smith S (2009) 'International student-workers in Australia: A new vulnerable workforce' 22 Journal of Education and Work 1 
O’Shea T (2017) Evidence to Education and Employment Legislation Committee, Senate, Canberra, 2 March

Productivity Commission (2015) Workplace Relations Framework Inquiry, Inquiry Report 76, Government of Australia, Canberra

Reilly A (2012) 'Protecting vulnerable migrant workers: The case of international students' 25 Australian Journal of Labour Law 181

Reilly A, Howe J, Berg L and Farbenblum B (2017, on file with authors) International Students' Engagement with The Fair Work Ombudsman

Senate Education and Employment References Committee (2016) A National Disgrace: The Exploitation of Temporary Work Visa Holders

Tham J-C (2016) Submission No 3: Supplementary Submission to Senate Standing Committee on Education and Employment, Inquiry into The Impact of Australia's Temporary Work Visa Programs on the Australian Labour Market and On the Temporary Work Visa Holders, 16 September

Underhill E and Rimmer M (2015) 'Layered vulnerability: Temporary migrants in Australian horticulture' 58 Journal of Industrial Relations 608

Unite Organiser (2016) personal communication, 5 May

Weil D (2010) 'Improving workplace conditions through strategic enforcement: A report to the Wage and Hour Division', United States Department of Labour 
Wilson N (2012) 'Update from the Fair Work Ombudsman', Paper presented at the Industrial Relations Summit, Sydney, 5 March 